\title{
Professional and ethical dilemmas of economists (In memoriam János Kornai, 1928-2021)
}

\author{
PÉTER MIHÁLYI*
}

Department of Economics, Corvinus University of Budapest, Budapest, Fővám tér 8, H-1093, Hungary

Received: November 1, 2021 • Accepted: November 1, 2021

(c) 2021 The Author(s)

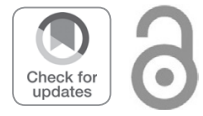

\begin{abstract}
János Kornai, the most distinguished Hungarian economist passed away on 18 October 2021. This short essay, written by a long-time disciple of Kornai tries to prioritize his scientific achievements spreading over six decades. The conclusion is that Kornai's most important contribution to the principles of economics was already presented in his 1971 book, entitled Anti-equilibrium, and without this book his most respected later works and his other original concepts, like the soft budget constraint or the shortage economy, cannot be understood.
\end{abstract}

\section{KEYWORDS}

general equilibrium theory, shortage economy, socialism, China

\section{JEL CLASSIFICATION INDICES}

A13, B24, B41, D50

For at least two decades in October of every year, I hoped that a life-long friend of my parents and my supporting mentor since adolescence, János Kornai would receive the Nobel Prize in Economics. This autumn, another year passed and, once again, not him, but others were crowned by the Swedish Academy. Alas, we all know that he cannot receive the prize in the future either - having passed away on 18 October 2021, after an enviably long, beautiful life and a 69 year long academic career. Nevertheless, even without the Nobel award, János was the most important Hungarian economist of all time, widely known in his home country and worldwide. His books were translated into 20 languages - including Sinhalese. After a long illness, he passed away at home, surrounded by his beloved family. He was 93 years old.

\footnotetext{
*Corresponding author. E-mail: peter@mihalyi.com
} 


\section{A FANTASTIC CAREER}

Kornai completed his schooling in Budapest, where he endured decades of racial-ethnic discrimination and persecution as a teenager and young adult, where he became a convinced communist after the fall of the fascist regime in 1945, and where he became disillusioned with the Marxist-Leninist system of thought between 1953 and $1956 .{ }^{1} \mathrm{He}$ was extremely lucky, because he was less than 30 years old at the time, but thanks to his German language skills from home and from the elite German-language grammar school in Budapest, he had already understood the basic works of Karl Marx - when these books were not yet available in Hungarian translation at the time. And then, as a leading economic journalist, editor and reporter of the communist party-state regime between 1947 and 1955, he accumulated a deep and wide-ranging knowledge of the actual functioning of the socialist economic system, based - inter alia - on his personal contacts with the highly placed managers of the economy. In other words, he started from an exceptionally fortunate position, when he began to learn economics as an academic discipline following his own intuition, from books and journals borrowed from libraries. He studied modern (Western) economics inspired by the Anglo-Saxon ideas, which at that time was not taught in any university in Hungary. Already then, he rightly felt that he would have wasted time and energy by formally enrolling in a Hungarian or Soviet university, as most of his contemporaries did between 1948 and 1956. But it was evident only in retrospect that the socialist economies based on Marxist-Leninist ideology were as similar as biologically similar species. It did not matter much in which country you studied the so-called planned economic system. The most basic relationships were very, very similar in all countries - from Albania to Yugoslavia. So Kornai made the right decision in choosing the easiest solution for him given his circumstances: analysing the functioning of the Hungarian economy in his $1956 \mathrm{PhD}$ thesis. What he found, it turned out afterwards, could have been discovered in any other socialist country.

Kornai also rightly recognised that, ultimately, the only way to break into the international forefront of economics was publishing in English. From the outset, therefore, he invested a great deal of effort in making all his articles, books and even interviews in Hungarian, which he considered to be more important, available in English, too. Thanks to this conscious strategy, between 1967 and 2019 (i.e., in a time span of 52 years), Acta Oeconomica published nearly 30 Kornai articles (Table 1), more than any other English-language academic journal. ${ }^{2}$ In fact, there were three calendar years (1981, 1995 and 1998) when two Kornai papers appeared in our journal in the same year. Needless to say, the author of this memorial essay and his predecessors at the head of our quarterly journal were always honoured to have so many of Kornai's manuscripts. Indeed, in recent decades, when it has become clear that the prestige of a scientific journal is determined primarily by the number of references to its articles and where they are cited, the publication of an original Kornai article has contributed greatly to our journal's impact factor.

\footnotetext{
${ }^{1}$ A recently written recollection of his current thoughts pertaining to the 1956 anti-communist uprising can be found in Kornai (2021).

${ }^{2}$ The closest ones are Economics of Planning (5 articles), Economics of Transition and Econometrica (4-4 articles).
} 
Table 1. János Kornai's scientific papers, essays, book reviews, obituaries and interviews published by Acta Oeconomica in 52 years (1967-2019)

\begin{tabular}{|c|c|c|c|c|c|c|c|}
\hline & Title & Co-author(s) & Type & Year & Vol. & No. & pp. \\
\hline 1 & $\begin{array}{l}\text { Application of an } \\
\text { Aggregate } \\
\text { Programming Model } \\
\text { in Five Year Planning }\end{array}$ & Zsuzsa Újlaki & Modelling & 1967 & 2 & 4 & $327-344$ \\
\hline 2 & $\begin{array}{l}\text { Value and } \\
\text { Reproduction. An } \\
\text { Attempt at Working } \\
\text { Out a Mathematical } \\
\text { Model of the Marxian } \\
\text { Theory of Value and } \\
\text { Reproduction }\end{array}$ & & $\begin{array}{l}\text { Book review (author: } \\
\text { András Bródy) }\end{array}$ & 1969 & 4 & 4 & $423-428$ \\
\hline 3 & $\begin{array}{l}\text { Economic Systems } \\
\text { Theory and General } \\
\text { Equilibrium Theory }\end{array}$ & & $\begin{array}{l}\text { Critique of the General } \\
\text { Equilibrium Theory } \\
\text { (GET) }\end{array}$ & 1971 & 6 & 4 & $297-317$ \\
\hline 4 & $\begin{array}{l}\text { Macrofunctions } \\
\text { Computed on the } \\
\text { Basis of Plan }\end{array}$ & $\begin{array}{l}\text { Zsuzsa Dániel, } \\
\text { Judit Rimler }\end{array}$ & Modelling & 1972 & 8 & 4 & $375-406$ \\
\hline 5 & $\begin{array}{l}\text { The Measurement of } \\
\text { Shortage }\end{array}$ & - & Empirical & 1976 & 16 & $3-4$ & $321-344$ \\
\hline 6 & $\begin{array}{l}\text { The Oeuvre of Kenneth } \\
\text { J. Arrow }\end{array}$ & & Essay. Memoir & 1979 & 23 & $1-2$ & $193-203$ \\
\hline 7 & $\begin{array}{l}\text { 'Hard' and 'Soft' } \\
\text { Budget Constraint }\end{array}$ & & Critique of GET & 1980 & 25 & $3-4$ & $231-246$ \\
\hline 8 & $\begin{array}{l}\text { On the Difficulties and } \\
\text { Deficiencies of } \\
\text { Mathematical } \\
\text { Economic Research } \\
\text { in Hungary }\end{array}$ & & Modelling & $1981 a$ & 26 & $1-2$ & $175-198$ \\
\hline 9 & $\begin{array}{l}\text { Bródy András: Cycle } \\
\text { and Control }\end{array}$ & $\begin{array}{l}\text { András } \\
\text { Simonovits }\end{array}$ & Book review & $1981 b$ & 26 & $3-4$ & $409-414$. \\
\hline 10 & $\begin{array}{l}\text { Comments on Tibor } \\
\text { Liska's Concept of } \\
\text { Entrepreneurship }\end{array}$ & & Essay & 1982 & 28 & $3-4$ & $455-460$ \\
\hline 11 & $\begin{array}{l}\text { Equilibrium as a } \\
\text { Category of } \\
\text { Economics }\end{array}$ & & Critique of GET & 1983 & 30 & 2 & 145-159. \\
\hline 12 & $\begin{array}{l}\text { Softness of the Budget } \\
\text { Constraint - An } \\
\text { Analysis Relying on } \\
\text { Data of Firms }\end{array}$ & Ágnes Matits & Empirical & 1984 & 32 & $3-4$ & $223-249$ \\
\hline
\end{tabular}

(continued) 
Table 1. Continued

\begin{tabular}{|c|c|c|c|c|c|c|c|}
\hline & Title & Co-author(s) & Type & Year & Vol. & No. & pp. \\
\hline 13 & $\begin{array}{l}\text { On the Explanatory } \\
\text { Theory of Shortage. } \\
\text { Comments on Two } \\
\text { Articles by K. A. Soós }\end{array}$ & & $\begin{array}{c}\text { Polemics. Critique of } \\
\text { GET }\end{array}$ & 1985 & 34 & $1-2$ & $145-164$ \\
\hline 14 & $\begin{array}{l}\text { The Chinese Economic } \\
\text { Reform - As Seen by } \\
\text { Hungarian } \\
\text { Economists }\end{array}$ & Zsuzsa Dániel & General theory & 1986 & 36 & $3-4$ & 289-305 \\
\hline 15 & $\begin{array}{l}\text { The Historical Mission } \\
\text { of Heresy. György } \\
\text { Péter, the Reform } \\
\text { Economist }\end{array}$ & & Essay, Memoir & 1993 & 45 & $1-2$ & $89-100$ \\
\hline 16 & $\begin{array}{l}\text { Lasting Growth as the Top } \\
\text { Priority: } \\
\text { Macroeconomic } \\
\text { Tensions and } \\
\text { Government Economic } \\
\text { Policy in Hungary }\end{array}$ & & Hungarian economy & 1995a & 47 & $1-2$ & $1-38$ \\
\hline 17 & $\begin{array}{l}\text { The Dilemmas of } \\
\text { Hungarian Economic } \\
\text { Policy }\end{array}$ & & Hungarian economy & $1995 b$ & 47 & $3-4$ & $227-248$ \\
\hline 18 & $\begin{array}{l}\text { In Memoriam Tamás } \\
\text { Lipták }\end{array}$ & & Obituary & $1998 a$ & 49 & $3-4$ & $461-463$ \\
\hline 19 & $\begin{array}{l}\text { Scitovsky Tibor: } \\
\text { Memoirs of a Proud } \\
\text { Hungarian }\end{array}$ & & Book review & $1998 b$ & 49 & $3-4$ & $465-467$ \\
\hline 20 & $\begin{array}{l}\text { Equilibrium, Growth } \\
\text { and Reform }\end{array}$ & & Hungarian economy & 2006 & 56 & 4 & $371-397$ \\
\hline 21 & $\begin{array}{l}\text { Coffee and Tea: Some } \\
\text { Comments on } \\
\text { Reforming the } \\
\text { System of Health } \\
\text { Insurance in Hungary }\end{array}$ & & Healthcare reform & 2008 & 58 & 2 & 239-261 \\
\hline 22 & $\begin{array}{l}\text { Where is the Line } \\
\text { Between } \\
\text { Independent } \\
\text { Economic Analysis } \\
\text { and Active Policy } \\
\text { Making? The } \\
\text { Example of the } \\
\text { Independent Fiscal } \\
\text { Councils }\end{array}$ & & Essay & 2010 & 60 & 3 & 249-254 \\
\hline
\end{tabular}

(continued) 
Table 1. Continued

\begin{tabular}{|c|c|c|c|c|c|c|c|}
\hline & Title & Co-author(s) & Type & Year & Vol. & No. & pp. \\
\hline 23 & $\begin{array}{l}\text { What "Economics of } \\
\text { Shortage" and "The } \\
\text { Socialist System" } \\
\text { Have to Say to the } \\
\text { (Hungarian) Readers } \\
\text { Today: An } \\
\text { Introductory Study to } \\
\text { the First Two } \\
\text { Volumes of the Life's } \\
\text { Work Series }\end{array}$ & & Hungarian economy & 2012 & 62 & 3 & $365-384$ \\
\hline 24 & $\begin{array}{l}\text { Centralization and } \\
\text { Market Reform: An } \\
\text { Introductory Study to } \\
\text { Volume III of the } \\
\text { Life's Work Series }\end{array}$ & & Preface & 2013 & 63 & 3 & $335-366$ \\
\hline 25 & $\begin{array}{l}\text { The Soft Budget } \\
\text { Constraint: An } \\
\text { Introductory Study to } \\
\text { Volume IV of the } \\
\text { Life's Work Series }\end{array}$ & & Preface & 2014 & 64 & S1 & $25-79$ \\
\hline 26 & $\begin{array}{l}\text { The System Paradigm } \\
\text { Revisited: } \\
\text { Clarifications and } \\
\text { Additions in the Light } \\
\text { of Experiences in the } \\
\text { Post-Socialist Region }\end{array}$ & & Critique of GET & 2016 & 66 & 4 & $547-596$ \\
\hline 27 & $\begin{array}{c}\text { Frankenstein's Moral } \\
\text { Responsibility }\end{array}$ & & Essay on China. Memoir & 2019 & 69 & 4 & $485-494$ \\
\hline 28 & $\begin{array}{l}\text { Economics and } \\
\text { Psychology (An } \\
\text { Interview About his } \\
\text { Book of 'Economics } \\
\text { of Shortage') (Tibor } \\
\text { Engländer, László } \\
\text { Halász) }\end{array}$ & & Intenview & 1981 & 26 & $3-4$ & $389-401$ \\
\hline 29 & $\begin{array}{l}\text { An Interview with János } \\
\text { Kornai (Katalin } \\
\text { Bossányi) }\end{array}$ & & Interview & 1990 & 42 & $3-4$ & $315-328$ \\
\hline
\end{tabular}


Table 2. The complete summary list of János Kornai's academic publications, 1952-2021

\begin{tabular}{|c|c|c|c|c|}
\hline & & 1952-1989 & $1990-2021$ & 1952-2021 \\
\hline & Period length & 37 years & 31 years & 69 \\
\hline 1 & Books & 9 & 10 & 19 \\
\hline 2 & Edition of books in Hungarian & 2 & 2 & 4 \\
\hline 3 & Edition of books in foreign languages & 2 & 6 & 8 \\
\hline 4 & Collected writings (published earlier) & 2 & 5 & 7 \\
\hline 5 & Papers in Hungarian & 102 & 105 & 207 \\
\hline 6 & Original papers in foreign languages & 39 & 31 & 70 \\
\hline 7 & $\sim$ Papers (re)published in Acta Oeconomica & 14 & 13 & 27 \\
\hline 8 & Working papers in Hungarian & 30 & 3 & 33 \\
\hline 9 & Original working papers in foreign languages & 15 & 16 & 31 \\
\hline 10 & $\begin{array}{l}\text { Long intenviews published in Hungarian, } \\
\text { mainly in journals }\end{array}$ & 2 & 23 & 25 \\
\hline 11 & $\begin{array}{l}\text { Long interviews published in foreign } \\
\text { languages, mainly in journals }\end{array}$ & 8 & 21 & 29 \\
\hline 12 & $\begin{array}{l}\text { Short articles and short interviews in } \\
\text { Hungarian, mainly in daily and weekly } \\
\text { newspapers }\end{array}$ & 27 & 59 & 86 \\
\hline
\end{tabular}

Notes: If the original publication was in Hungarian, the translations into foreign languages were not counted separately. The periodisation underscores the importance of the regime change in 1989.

Source: Compiled with the assistance of Ádám Kerényi, one of the young disciples of Professor Kornai, using (predominantly) János Kornai's homepage, http://kornai-janos.hu/full\%20publist.html, as of 30 September, 2021. See also Kerényi (2013).

János's visible real academic career started in Budapest, at the Institute of Economics of the Hungarian Academy of Sciences in 1955. He rose to the top by 1986 at the age of 58, when he received an occasional professorial appointment at Harvard University, followed in 1991 by the Allie S. Freed Professorship, a permanent appointment he held until 2002. He retired of his own wish from Harvard as Professor Emeritus in 2002. From the 1980s onwards, he spent half of the academic year in the Hungarian capital and the other half at Harvard in Boston, roughly equally divided. This enabled him to work as a founding fellow of the Collegium Budapest Institute for Advanced Study from 1912 to 2011. János was elected a member of the Hungarian Academy of Sciences in 1976. He received the title of Honorary Professor Emeritus at the Corvinus University of Budapest in 2011, the duties of which he fulfilled almost until his last months of life. A succinct summary of his publications is presented in Table 2. 


\section{THE FOUR MOST IMPORTANT SCIENTIFIC CONTRIBUTIONS OF KORNAI}

A few days after the final closure of his life's work, it is perhaps premature to take stock, and thereby, highlight Professor Kornai's most important achievements among so many. ${ }^{3}$ Nevertheless, putting aside all personal and national sympathies, I am confident that with his accomplished academic legacy, János would have deserved the highest international award for at least four impressive, intrinsically linked findings.

First, it is beyond any doubt that his 644-page magnum opus - Kornai (1992) - gave the most adequate and convincing explanatory narrative of the worldwide communist system.

Second, the construction of the soft budget constraint (SBC) concept from 1975 onwards was an equally impressive academic achievement. The term SBC has become so widespread in the economic literature that with a little bit of exaggeration we can compare it to the importance of the concept of black hole or DNA in the vocabulary of physicists or biologists, respectively. Kornai has borrowed the term SBC from medicine, implying the bundle of visible problematic symptoms of a disease which otherwise in a healthy organism are not present. According to this definition, under "normal" circumstance the actors of the economy - the firms, the households and the various institutions of the public sector - operate with a hard budget constraint, which means that these actors cannot spend more than their revenues are and the size of this revenue depends on the prevailing market prices which they cannot unilaterally influence. If these agents wish to spend beyond this limit, they can borrow money, but all loans must be paid back at the contractual date with a pre-agreed interest. Kornai's remarkable insight was that SBC is present to a greater or lesser extent in all economies. The softer the fiscal constraint, the more an economy can be said to be close to the ideal-typical socialist economy. There are glaring shortages of all resources in the market and a weak capacity for innovation. And vice versa: the harder is the budget constraint, the more the economy shows the characteristics of the capitalist market economies: cyclical unemployment, ${ }^{4}$ large income and wealth disparities (Kornai 1980, 2014a, 2018).

Third, János Kornai introduced his supermarket metaphor ${ }^{5}$ in 1979 to challenge the theory of the third way, as an optimal hybrid between capitalist and communist rules. But, the socioeconomic systems, he argued, cannot be constructed from randomly or scientifically selected pieces, similar to customers in a supermarket, who are free to put into their shopping trolley whatever they find on the shelves. Systems, like socialism ${ }^{6}$ or capitalism, are not made of separate building blocks fixed together with screws or mortar. Their interrelatedness is like a genetic program of

\footnotetext{
${ }^{3}$ In a 2017 public lecture, the transcript of which is available in Hungarian only (Kornai 2019a), János made a self-critical remark about his very extensive and colourful research palette. If your life-long research is focused on a single subject, you have a better chance to become your own idea-promoter by writing about the same issues many-many times, he stated. By contrast, he continued, if you jump from one research subject to next frequently (as he did), your chances to make an impact on your peers is much smaller. After all, as he bitterly noted, commercial marketing was also based on frequent repetitions.

${ }^{4}$ In a private conversation, Kornai once said to the present writer that for him the term "equilibrium unemployment" or "natural rate of unemployment" were cynical oxymorons.

${ }^{5}$ In his Memoir, Kornai (2006, p. 282.) recalled that he had used the supermarket metaphor for the first time in the Q\&A part of his 1979 Geary Lecture in Dublin.

${ }^{6}$ In all his writings, Kornai used socialism and communism as synonyms.
} 
procreation. All newborn cats are similar to each other, whether small or big. In the same way, all socialist (or capitalist) systems likewise are somewhat similar to each other. In several later works - for example in Kornai (1990) -, he formulated the same idea as the "affinity thesis" according to which the bureaucratic model of coordination has a natural affinity for (strong linkage to) stateowned property, while market coordination has a natural affinity for private property. By contrast, the linkage between market coordination and state property is weak, meaning that one cannot use the market as a neutral instrument to promote state ownership.

The fourth major achievement in Kornai's ouvre was, in fact, the most important in his own assessment. As can be read in his memoirs, "Anti-Equilibrium is not merely an item on my list of publications. It was the most ambitious enterprise of my career as a researcher" $(2006$, p. 197). Let us start our brief investigation with a question. Is economics conceivable without the concept of equilibrium? In the 1983 Okun Lectures, three years before his untimely death, Nicholas Kaldor (1972), the Hungarian-born British economist, a friend of János Kornai gave an affirmative answer to this question: yes, economics is better off without equilibrium (Kaldor 1985, p. 5). In reality, more than a decade earlier, by choosing an even more provocative book-title, AntiEquilibrium (AE for short), had already given the same answer. In real life, economic actors households, firms or national economies - are never in a position, which can be meaningfully called "equilibrium". They always act under the binding constraints. Capitalist economies are inherently demand-constrained, while the socialist regimes are always resource-constrained (Mihályi 2017b).

Beyond Kaldor, Kornai (1971) was not alone with his critique of the General Equilibrium Theory (GET). A thorough analysis ${ }^{7}$ of the Nobel Prize Lectures of all economists showed that 8 laureates - Hayek, Simon, Solow, Havelmo, Coase, North, Sen, and Kahneman - emphatically stated in their addresses that the neoclassical theory was wrong, in whole or in part, on either empirical or theoretical grounds. All of them said that the equilibrium theory could not be true.

Beyond all this, it is also noteworthy that $\mathrm{AE}$ was well ahead of its time in emphasising that:

(i) economics should draw from biology, rather than physics, as its methodological underpinning;

(ii) evolutionary logic requires a different type of decision-making in simple, routine matters, as opposed to large and important decisions;

(iii) the most important production processes are non-linear, with increasing returns to scale being the rule, rather than the exception in modern capitalist economies and - in conclusion - that there is no such thing as general equilibrium. In modern societies, goods and services are either in shortage (Socialism) or in a state of oversupply (Capitalism). It is either a buyers' market or sellers' market. ${ }^{8}$

With the benefit of hindsight, however, it is clear that Kornai's 1971 book did not have such a deep international impact that the author and his many enthusiastic readers at home and abroad had hoped for. Why? AE was written in four years, between 1967 and 1971, with the semifinished product (an essay-length study) and the final product being available in English at about the same time as the Hungarian version. Kornai spent decades at American universities, has been

${ }^{7}$ See Offer - Söderberg (2016, p. 65).

${ }^{8}$ See Mihályi (2013) for a detailed analysis of this narrative. 
a member of numerous international academic fora, his former students are now professors at major universities around the world. So, it cannot be said that language barriers or geographical isolation were the obstacles to his breakthrough. It is still regularly cited today, but the mainstream of our science relies on GET, the one created by Walras (1874), Samuelson (1948), Arrow - Debreu (1954) and Debreu (1959) as their professional mother tongue.

In other words, the paradigm shift Kornai hoped for and called for has not taken place. In 2021, the neoclassical vision is still be taught at the world's best economics universities and in Hungary, as well.

That economic agents always behave rationally, and that, since there is perfect competition in atomized markets, supply and demand processes lead to equilibrium in all markets. In 440 pages, $\mathrm{AE}$ explains and demonstrates that these are grossly contradictory assumptions and that the conclusions are therefore untenable. Yet, to this day, traditional economics seems to have been able to extend its own boundaries to accommodate diametrically opposed theories at the margins (e.g., imperfect competition, bounded rationality, etc.). GET has changed in many ways since 1971, but this change is not attributed to the AE by the new generation of economists. Simply because they have hardly heard about the book, if at all.

\section{THE ASSESSMENT OF THE RECENT U-TURN IN CHINA}

In 1985 Kornai spent four weeks in China. In many ways, this seemed to be the highest point of his career as a reform economist and policy adviser. The reforms initiated by Deng Xiaoping in 1978 were already well under way in the world's most populous country, and the positive results of the changes were already visible. ${ }^{9}$ From his 19 books, 15 were translated into Chinese. Thus, many indications suggested that China was able to make a rapid and peaceful transition from a socialist economic model to a market economy model, partly on the basis of Kornai's ideas and advice. Kornai also had reason to be proud of the fact and draw optimistic conclusions from it, that his former Harvard PhD students had been elevated into influential positions in Chinese economic policy. Up until 2018, Kornai's numerous writings and statements were, if not entirely uncritical, ${ }^{10}$ but essentially supportive of the Chinese reform process.

Therefore, it came as a surprise when, in February 2018, at a conference devoted to his $90^{\text {th }}$ birthday, János stated publicly in his own conference closing speech that China made a U-turn. ${ }^{11}$ Under the dictatorial leadership of President Xi Jinping the country had essentially restored the dominant institutions of the communist political and economic establishment. Perhaps it is even better to say that the subsequent Chinese leaders after Deng had never completely dismantled them. Following the conference, Kornai expressed his views in an op-ed article of the Financial Times (Kornai 2019b) and in other articles, including a 2019 paper in Acta Oeconomica. With this insight Kornai was months or even two years,

\footnotetext{
${ }^{9}$ It has been seldomly stated in comparative studies that the reforms linked to political leadership of Deng had predated by a large time margin the so-called post-communist reforms in Eastern Europe and the Soviet Union, starting in 1989 and 1990, respectively.

${ }^{10}$ See e.g., Kornai (2014b).

${ }^{11}$ See Mihalyi (2020) the selected papers of this conference in Piroska - Rosta (2020) together with the transcript of Kornai's talk mentioned above.
} 
ahead of the world. Seven months later, George Soros (2020) alarmed the European Union. He published an op-ed (under the telling title "Europe Must Recognize China for What It Is") containing words very similar to those written by Kornai: "Neither the European public nor European political and business leaders fully understand the threat presented by Xi Jinping's China." 12

After the East European and Russian regime change in 1990, Kornai and most Western commentators expected that as market integration and private property expanded, China eventually would also turn into a liberal democracy. Prior to the worldwide fall of communism, Kornai offered three primary criteria for determining whether a country was socialist or capitalist. In a later, 2016 Acta Oeconomica paper he amended this first three criteria by adding six secondary ones. On this basis, his conclusion was that under President Xi's rule while capitalist elements remained strong, in the final analysis, the country was on its way back to where it was before 1978. ${ }^{13}$ Present-day China, under the leadership of $\mathrm{Xi}$ Jinping, is returning to the communist, dictatorial practices. The regime retains and even extends governmental interference into markets and private property. In the light of Kornai's supermarket metaphor, presented above, such a system may become unsustainable. Whether it is untenable already in the short-run remains to be seen. Only history can tell, but Kornai's theory predicts internal failure and - in view of the size of the China - and external conflicts.

As I sadly stated at the beginning of this memorial article, the Prize Committee of the Royal Swedish Academy of Sciences did not award János Kornai with the Nobel Prize and - according to the rules - this prize cannot be donated post humus. According to the hearsays of the profession, Kornai had been nominated more than one times, but on all occasions other distinguished economists were chosen by the majority of Prize Committee. Whether this is true or not, we cannot know. The deliberations of the Swedish Academy are confidential for 50 years. The first prize was given in 1969, thus the materials of the first few years are already available for researchers. Our children and grandchildren will certainly know at some point more about this important story.

Budapest, 27 October 2021.

Péter MIHÁLYI

Editor-in-Chief

Acta Oeconomica

\footnotetext{
${ }^{12}$ In the spirit of Kornai's assessment of the recent Chinese developments, Acta Oeconomica published 8 outstanding papers to China in its 2020 Special Issue, under the title "2020 - The Year of China" (Vol. 70.).

${ }^{13}$ In a Special Issue of Public Choice, in honouring János Kornai, a paper by Mihályi - Szelényi (2021) introduced another 11 criteria (thus providing 20 quantifiable metrics all together) to decide whether present day China is a communist or a capitalist system.
} 


\section{REFERENCES}

Arrow, K. J. - Debreu, G. (1954): Existence of Equilibrium for a Competitive Economy. Econometrica, 22(3): 265-290.

Debreu, G. (1959): Theory of Value. New York: Wiley\&Sons.

Kaldor, N. (1972): The Irrelevance of Equilibrium Economics. Reprinted in 1978: Further Essays on Economic Theory. London: Duckworth Publishers.

Kaldor, N. (1983, 1985): Economics without Equilibrium (Arthur M. Okun Memorial Lectures). Armonk, N.Y.: M.E. Sharpe, Inc.

Kerényi, Á. (2013): Conference in Honour of János Kornai on the Occasion of his $85^{\text {th }}$ Birthday. Acta Oeconomica, 63(2): 233-237.

Kornai, J. (1971): Anti-equilibrium. On Economic Systems Theory and the Tasks of Research. Amsterdam: North-Holland Publishing Co. (2nd edition in 1991, by Augustus M. Kelley Publishers).

Kornai, J. (1980): Economics of Shortage. Amsterdam: North-Holland Publishing Co.

Kornai, J. (1990): The Affinity between Ownership Forms and Coordination Mechanisms: The Common Experience of Reform in Socialist Countries. Journal of Economic Perspectives, 4(3): 131-147.

Kornai, J. (1992): The Socialist System. The Political Economy of Communism. Oxford: Clarendon Press.

Kornai, J. (2006): By Force of Thought. Irregular Memoirs of an Intellectual Journey. Cambridge, MA London, UK: The MIT Press.

Kornai, J. (2014a): Dynamism, Rivalry, and the Surplus Economy. Oxford: Oxford University Press.

Kornai, J. (2014b): Példaképünk: Kína? (Can China Set us an Example?) In: Kolosi, T. - Tóth, I. Gy. (eds): Társadalmi riport 2014. Budapest: TÁRKI, pp. 603-616. For an English translation, see https://www. kornai-janos.hu/Kornai2014_Can_China_Set_Us_an_Example.pdf.

Kornai, J. (2018): About the Value of Democracy and Other Challenging Research Topics. Closing remarks at the conference on February 22, 2018, celebrating Kornai's $90^{\text {th }}$ birthday. In: Piroska, D. - Rosta, M. (eds): Systems, Institutions and Values in East and West. Engaging with János Kornai's Scholarship. Budapest - New York: Central European University Press, pp. 203-209, http://retp.eu/index.php/retp/ article/view/52/54.

Kornai, J. (2019a): A gondolat erejével? A közgazdászok szakmai és politikai dillemáiról (With the Force of Thought? On the Professional and Political Dilemmas of Economists). Közgazdasági Szemle, LXVI (February): 117-133.

Kornai, J. (2019b): Economists Share Blame for China’s 'Monstrous' Turn: Western Intellectuals Must Now Seek to Contain Beijing. Financial Times, 10 July, p. 11.

Kornai, J. (2021): 1956 in Hungary: As I Saw it Then and as I See it Now. Public Choice, 187(1-2): $15-26$.

Mihályi, P. (2012): The Selected Works of János Kornai are Published in 10 Volumes - Foreword. Acta Oeconomica, 62(3): 363-364.

Mihályi, P. (2013): János Kornai’s Anti-Equilibrium, a Harbinger of Evolutionary Economics. Acta Oeconomica, 63(3): 367-375. Republished in: Hámori, B. - Rosta, M. (eds): Constraints and Driving Forces in Economic Systems. Studies in Honour of János Kornai. Cambridge: Cambridge Scholars Publishing, 2016, pp. 77-86.

Mihályi, P. (2017a): The Motivation of Business Leaders in Socialist and Market-Based Systems (An Essay to Celebrate the $90^{\text {th }}$ Birthday of János Kornai). Economics and Business Review (former name: Poznan University Economics Review), 17(3): 116-127. 
Mihályi, P. (2017b): Kaldor and Kornai on Economics without Equilibrium - Two Life Courses. Acta Oeconomica, 67(S): 47-66.

Mihályi, P. (2018): János Kornai Turns 90 on January 21. Editor's Preface. Acta Oeconomica, 68(S): 3-8. Mihályi, P. (2020): The Theories of János Kornai and a Less-Known Hungarian Economist, Ferenc Jánossy, on Unbalanced Economic Growth. In: Piroska, D. - Rosta, M. (eds): Systems, Institutions and Values in East and West. Engaging with János Kornai's Scholarship. Budapest - New York: Central European University Press, pp. 51-67.

Mihályi, P. - Szelényi, I. (2021): Kornai on the Affinity of Systems: Is China Today an Illiberal Capitalist System or a Communist Dictatorship? Public Choice, 187(1/2): 197-216.

Offer, A. - Söderberg, G. (2016): The Nobel Factor. The Prize in Economics, Social Democracy, and the Market Turn. Princeton and Oxford: Oxford University Press.

Piroska, D. - Rosta, M. (eds) (2020): Systems, Institutions and Values in East and West. Engaging with János Kornai's Scholarship. Budapest - New York: Central European University Press, pp. 51-67.

Samuelson, P. (1948): Economics. An Introductory Analysis. McGraw-Hill Book Company.

Soros, G. (2020): Europe must Recognize China for What it is. Project Syndicate, 11 February, https://www. project-syndicate.org/commentary/china-huawei-threat-to-european-values-by-george-soros-2020-02.

Walras, L. (1874): Élements d'économie politique pure; ou théorie de la richesse sociale. Lausanne: L. Corbaz, http://www.archive.org/details/lmentsdconomiep01walrgoog.

Open Access. This is an open-access article distributed under the terms of the Creative Commons Attribution 4.0 International License (https://creativecommons.org/licenses/by/4.0/), which permits unrestricted use, distribution, and reproduction in any medium, provided the original author and source are credited, a link to the CC License is provided, and changes - if any - are indicated. (SID_1) 